\title{
IMPLEMENTASI KETENTUAN ANCAMAN PIDANA DALAM PERATURAN DAERAH KOTA TASIKMALAYA NOMOR 7 TAHUN 2015 TENTANG PENGENDALIAN DAN PENGAWASAN MINUMAN BERALKHOHOL DI KOTA TASIKMALAYA
}

\author{
Oleh: Dindin M. Hardiman, S.Sos., M.M., M.H. ${ }^{*}$
}

\begin{abstract}
The purpose of the establishment of City Regulation Tasikmalaya Number 7 Year 2015 on Control and Supervision of Alcoholic Beverages in Tasikmalaya City is to provide protection to the public from the negative impact of alcoholic beverages which includes the production, import, distribution, sales, serving and consumption activities held in Tasikmalaya City. Nevertheless, there are still violations against this law. This paper attempts to parse the implementation of this law and the constraints in implementing this law and the efforts made to overcome these obstacles.
\end{abstract}

Keywords: Violations, Regional Regulations, Alcoholic Beverages.

\section{Abstrak}

Maksud dibentuknya Peraturan Daerah Kota Tasikmalaya Nomor 7 Tahun 2015 tentang Pengendalian dan Pengawasan Minuman Beralkohol di Kota Tasikmalaya adalah untuk memberikan perlindungan kepada masyarakat dari dampak negatif minuman beralkohol yang mencakup kegiatan produksi, impor, peredaran, penjualan, penyajian dan konsumsi yang dilaksanakan di Kota Tasikmalaya. Meskipun demikian, masih terjadi pelanggaran terhadap Perda ini. Tulisan ini berusaha mengurai implementasi Perda ini dan kendala-kendala dalam implementasi Perda ini serta upaya yang dilakukan untuk mengatasi kendala tersebut.

Kata kunci: Pelanggaran, Peraturan Daerah, Minuman Beralkohol.

\section{Pendahuluan}

Produksi Minuman Mengandung Etil Alkohol (selanjutnya disingkat MMEA) atau biasa dikenal sebagai minuman beralkohol di Indonesia sudah semakin meningkat. Hal ini disebabkan karena semakin banyaknya kebutuhan masyarakat tertentu akan minuman beralkohol, semakin banyaknya tempattempat hiburan yang menyediakan minuman ini, seperti club, cafe, bar, diskotik, dan sebagainya mulai dari kadar alkohol yang rendah hingga yang paling tinggi. Minuman beralkohol adalah minuman yang mengandung etanol. Etanol adalah bahan psikoaktif yang apabila dikonsumsi menyebabkan penurunan kesadaran. Minuman yang mengandung etanol dihasilkan dari penyulingan yang

\footnotetext{
* Dosen Tetap Fakultas Hukum Universitas Galuh
} 
diproduksi dengan cara fermentasi biji-bijian, buah-buahan atau sayursayuran (Aminudin, 2010: 8).

Menurut Pasal 1 Peraturan Menteri Perdagangan Republik Indonesia Nomor 20/M-DAG/PER/4/2014 tentang Pengendalian dan Pengawasan terhadap Pengadaan Peredaran dan Penjualan Minuman Beralkohol, menyatakan bahwa minuman beralkohol adalah minuman yang mengandung etanol atau etil alkohol $(\mathrm{C} 2 \mathrm{H} 5 \mathrm{OH})$ yang diproses dari bahan hasil pertanian yang mengandung karbohidrat dengan cara fermentasi dan destilasi atau fermentasi tanpa destilasi. Adapun dampak negatif dari minuman beralkohol dari segi kesehatan yaitu gangguan fisik, gangguan jiwa, gangguan terhadap keamanan dan ketertiban masyarakat, serta menimbulkan gangguan kesehatan jasmani dan rohani (Aminudin, 2010: 20).

Maraknya peredaran minuman beralkohol di Kota Tasikmalaya, menimbulkan keresahan seluruh masyarakat Kota Tasikmalaya yang notabene sebagai masyarakat yang religius dalam ketaatan pada prinsip keagamaan. Bertitik tolak hal tersebut, Pemerintah Daerah Kota Tasikmalaya pada tahun 2015 telah memberlakukan Peraturan Daerah Kota Tasikmalaya Nomor 7 Tahun 2015 tentang Pengendalian dan pengawasan Minuman Beralkohol di Kota Tasikamalaya. Pasal 9 Peraturan Daerah ini melarang menganai:

a. Menyimpan minuman beralkohol untuk kepentingan sendiri dan/ atau orang lain dengan maksud tidak untuk dijual.

b. Menyajikan minuman beralkohol untuk kepentingan sendiri dan/ atau orang lain dengan maksid tidak untuk dijual, dan

c. Mengkonsumsi minuman berlakohol.

Meskipun larangan mengkonsumsi minuman beralkohol telah digariskan dalam Pasal 9 huruf C Peraturan Daerah Kota Tasikmalaya pada tahun 2015, namun pada kenyataannya masih belum ditaati sebagaimana mestinya, karena masih sering adanya orang-orang yang terjaring sedang mengkonsumsi minuman beralkohol, padahal ketentuan pidana bagi mereka yang mengkonsumsi minuman beralkohol telah diatur dan ditentukan dalam Pasal 15 ayat (2) huruf $\mathrm{C}$ Perda ini yang menentukan ancaman pidana kurungan paling lama 6 (enam) bulan dan denda paling banyak Rp. 50.000.000,- (lima puluh juta rupiah). 


\section{Tinjauan Pustaka}

1. Pengendalian

Pengendalian adalah proses, cara, perbuatan, pengekangan terhadap kemajuan (tugas) dengan membandingkan hasil dan sasaran secara teratur serta menyesuaikan usaha (kegiatan) dengan hasil (KBBI, 2008: 686). Pengendalian menurut Terry dalam Subarsono (2005: 35) adalah sebagai suatu proses penentuan apa yang harus dicapai yaitu standar apa yang sedang dilakukan yaitu pelaksanaan, menilai pelaksanaan dan melakukan perbaikanperbaikan sehingga pelaksanaan sesuai dengan rencana yang selaras dan seimbang. Menurut Strong dalam Hasibuan (2010: 21) bahwa pengendalian adalah proses pengaturan berbagai faktor dalam suatu perusahaan agar sesuai dengan ketetapan-ketetapan dalam rencana.

Pengendalian merupakan pemantauan, pemeriksaan dan evaluasi yang dilakukan oleh pemerintah dalam suatu organisasi mengenai sumber-sumber yang ada untuk mencapai tujuan yang telah ditetapkan sebelumnya, secara terus-menerus dan berkesinambungan agar semua dapat berfungsi secara maksimal, efektif dan efisien. Adapun jenis-jenis pengendalian:

a. Pengendalian umpan balik (feedback control) memperoleh informasi mengenai aktivitas-aktivitas yang telah selesai dijalankan. Pengendalian ini memungkinkan perbaikan di masa mendatang dengan mempelajari apa yang terjadi di masa lampau. Oleh karena itu, tindakan perbaikan terjadi setelah kejadian.

b. Pengendalian simultan (concurrent control) menyesuaikan proses yang sedang berjalan. Mengendalikan aktivitas pemantauan yang terjadi saat ini untuk mencegah terjadinya penyimpangan yang terlalu jauh dari standarnya.

c. Pengendalian ke depan (feedforward control) mengantisipasi dan mencegah masalah-masalah. Pengendalian ini memerlukan perspektif jangka panjang.

Pengendalian dalam rangka pengawasan terhadap minuman beralkohol diterapkan kepada:

a. Importir minuman beralkohol, distributor, dan sub distributor;

b. Pengusaha Toko Bebas Bea (PTBB), penjual langsung, pengecer miuman beralkohol golongan $A, B$, dan $C$, serta penjual langsung dan/atau pengecer minuman beralkohol untuk tujuan kesehatan; 
c. Perizinan, standar mutu, impor, pelaksanaan, pengedaran dan penjualan minuman beralkohol golongan A, B, dan C. (Dikutip dari Dinas Koperasi Usaha Mikro, Kecil, dan Menengah serta Perdagangan Kota Tasikmalaya).

Pengendalian yang dilakukan oleh Pemerintah Kota Tasikmalaya terhadap penjualan dan/atau peredaran minuman beralkohol adalah bertujuan untuk menekan jumlah pengguna minuman beralkohol karena minuman beralkohol disalahgunakan di kalangan remaja dan anak-anak serta meminimalisasi tindak kriminal dan kenakalan remaja yang disebabkan oleh pikiran mereka yang terpengaruh oleh minuman beralkohol.

\section{Pengawasan}

Pengawasan adalah penilikan dan penjagaan (KBBI, 2008: 101). pengawasan adalah proses kegiatan yang membandingkan apa yang dijalankan, dilaksanakan, atau diselanggarakan, atau diselanggarakan dengan dasar apa yang dikehendaki, direncanakan, atau diperintahkan (Subarsono, 2005: 34). Nawawi (2013:16) menyatakan bahwa pengawasan yaitu penemuan dan penerapan cara dan peralatan untuk menjamin bahwa rencana telah dilaksanakan sesuai dengan tujuan.

Dedi (2015: 64) menyatakan bahwa pengawasan terhadap kebijakan pemerintah dapat dilakukan dengan cara sebagai berikut: pertama, pengawasan Intern yakni pengawasan yang dilakukan oleh suatu badan yang organisatoris atau struktural yang masih termasuk dalam lingkungan pemerintahan sendiri. Kedua, pengawasan ekstern yakni pengawasan yang dilakukan oleh organ atau lembaga yang secara organisatoris atau struktural berada diluar pemerintahan.

Tujuan pengawasan menurut Sukarno (1992:105) adalah sebagai berikut:

a. untuk mengetahui apakah sesuatu atau sebuah aturan berjalan dengan rencana yang digariskan;

b. untuk mengetahui apakah segala sesuatu dilaksanakan sesuai dengan instruksi serta asas-asas yang telah diintruksikan;

c. untuk mengetahui kesulitan-kesulitan, kelemahan-kelemahan, dalam bekerja;

d. untuk mengetahui segala sesuatu apakah berjalan dengan efisien;

e. untuk mencari jalan keluar, apabila ternyata dijumpai kesulitankesulitan, kelemahan-kelemahan atau kegagalan ke arah perbaikan. 


\section{Minuman Beralkohol}

Minuman Beralkohol sebagaimana tertuang dalam Pasal 1 Angka 5 Peraturan Daerah Kota Tasikmalaya Nomor 7 Tahun 2015 tentang Pengendalian dan Pengawasan Minuman Beralkohol, adalah minuman yang mengandung etil alkohol atau etanol $(\mathrm{C} 2 \mathrm{H} 5 \mathrm{OH})$ yang diproses dari bahan hasil pertanian yang mengandung karbohidrat dengan cara fermentasi dan destilasi atau fermentasi tanpa destilasi.

Minuman beralkohol adalah minuman yang mengandung etanol. Etanol adalah bahan psikoaktif dan konsumsinya menyebabkan penurunan kesadaran. Di berbagai negara, penjualan minuman beralkohol dibatasi ke sejumlah kalangan saja, umumnya orang-orang yang telah melawati batas usia tertentu (Subhi dan Taufik, 2004: 100)

Alkohol adalah zat yang paling sering disalahgunakan manusia. Alkohol diperoleh atas peragian/ fermentasi madu, gula, sari buah atau umbi-umbian. Dari peragian tersebut dapat diperoleh alkohol sampai $15 \%$ tetapi dengan proses penyulingan (destilasi) dapat dihasilkan kadar alkohol yang lebih tinggi bahkan mencapai $100 \%$. Kadar alkohol dalam darah maksimum dicapai 30-90 menit. Setelah diserap, alkohol/ etanol disebarluaskan ke seluruh jaringan dan cairan tubuh. Dengan peningkatan kadar alkohol dalam darah orang akan menjadi euforia, namun dalam penurunannya orang tersebut menjadi depresi (Subhi dan Taufik, 2004: 103).

Minuman beralkohol dapat digolongkan sebagai zat Psikotropika yaitu zat atau obat, baik alamiah maupun sintesis bukan narkotika, yang berkhasiat psikoaktif melalui pengaruh selektif pada susunan saraf pusat yang menyebabkan perubahan khas pada aktivitas mental dan perilaku. Oleh karena itu, minuman beralkohol tidak hanya menyebabkan mabuk, akan tetapi pada tingkat tertentu dapat menyebabkan kematian.

Pada tingkat kandungan $0,05-0,15 \%$ etanol di mana di dalam darah peminum akan mengalami kehilangan koordinasi, pada tingkat $0,15-0,20 \%$ etanol menyebabkan keracunan, pada tingkat $0,30-0,40 \%$ peminum hilang kesadaran dan pada tingkat yang lebih tinggi lagi yaitu $0,50 \%$ dapat menyebabkan kematian (Pasal 1 Angka 1 Undang-undang Nomor 5 tahun 1997 tentang Psikotropika). 
Bila dikonsumsi berlebihan, minuman beralkohol dapat menimbulkan Gangguan Mental Organik (GMO), yaitu gangguan dalam fungsi berpikir, merasakan dan berperilaku. Timbulnya GMO itu disebabkan reaksi langsung alkohol pada sel-sel saraf pusat. Karena sifat adiktif alkohol itu, orang yang meminumnya lama-kelamaan tanpa sadar akan menambah takaran/dosis sampai pada dosis keracunan atau mabuk (Anangsyah, 2000: $5)$.

Pasal 1 Peraturan Presiden Republik Indonesia Nomor 74 tahun 2013 Tentang Pengendalian dan Pengawasan Minuman Beralkohol, menjelaskan bahwa yang dimaksud dengan minuman beralkohol adalah minuman yang mengandung etil alkohol atau etanol $(\mathrm{C} 2 \mathrm{H} 5 \mathrm{OH})$ yang diproses dari bahan hasil pertanian yang mengandung karbohidrat dengan cara fermentasi dan destilasi atau fermentasi tanpa destilasi

Golongan minuman beralkohol diatur pada Pasal 3 ayat (1) Peraturan Presiden Republik Indonesia Nomor 74 tahun 2013 ini menyebutkan bahwa minuman beralkohol dikelompokkan sebagai berikut:

a. Minuman Beralkohol golongan $\mathrm{A}$ adalah minuman yang mengandung etil alkohol atau etanol $(\mathrm{C} 2 \mathrm{H} 5 \mathrm{OH})$ dengan kadar sampai dengan $5 \%$ (lima persen);

b. Minuman Beralkohol golongan $\mathrm{B}$ adalah minuman yang mengandung etil alkohol atau etanol $(\mathrm{C} 2 \mathrm{H} 5 \mathrm{OH})$ dengan kadar lebih dari 5\% (lima persen) sampai dengan 20\% (dua puluh persen); dan

c. Minuman Beralkohol golongan $\mathrm{C}$ adalah minuman yang mengandung etil alkohol atau etanol $(\mathrm{C} 2 \mathrm{H} 5 \mathrm{OH})$ dengan kadar lebih dari 20\% (dua puluh persen) sampai dengan 55\% (lima puluh lima persen)

Pasal 3 ayat (2) Peraturan Presiden Republik Indonesia Nomor 74 tahun 2013 menjelaskan bahwa minuman beralkohol sebagaimana dimaksud pada ayat (1) ditetapkan sebagai barang dalam pengawasan. Selanjutnya dalam Pasal 3 ayat (3) dijelaskan bahwa pengawasan sebagaimana dimaksud pada ayat (2) meliputi pengawasan terhadap pengadaan minuman beralkohol yang berasal dari produksi dalam negeri atau asal impor serta peredaran dan penjualannya. 
Sementara itu, dalam Pasal 7 ayat (1) Peraturan Presiden Republik Indonesia Nomor 74 tahun 2013 bahwa minuman beralkohol golongan A, golongan $\mathrm{B}$, dan golongan $\mathrm{C}$ hanya dapat dijual di:

a. hotel, bar, dan restoran yang memenuhi persyaratan sesuai peraturan perundang-undangan di bidang kepariwisataan;

b. toko bebas bea; dan

c. tempat tertentu selain huruf a dan b yang ditetapkan oleh Bupati/Walikota dan Gubernur untuk Daerah Khusus Ibukota Jakarta.

4. Pelanggaran

Istilah pelanggaran di dalam pergaulan masyarakat sehari-hari sudah tidak asing lagi didengar, karena kata pelanggaran diartikan sebagai suatu perbuatan yang melanggar hukum termasuk di dalamnya undang-undang, Peraturan Pemerintah dan Peraturan Perundang-undangan lainnya.

Menurut Kamus Besar Bahasa Indonesia (2008: 809) istilah pelanggaran adalah perbuatan (perkara) melanggar tindak pidana yang lebih ringan daripada kejahatan. Sedangkan menurut Kamus Hukum karya Andi Hamzah (1986: 44) dijelaskan bahwa pelanggaran adalah perbuatan yang melanggar Peraturan Perundang-undangan tetapi dibedakan daripada kejahatan.

Selanjutnya, menurut Wirjono Prodjodikoro (2003: 33) pengertian pelanggaran adalah "overtredingen" atau pelanggaran berarti suatu perbuatan yang melanggar sesuatu dan berhubungan dengan hukum, berarti tidak lain dari pada perbuatan melawan hukum. Sedangkan menurut Bambang Poernomo (2002: 40) pelanggaran adalah politis on recht dan kejahatan adalah crimineel on recht. Politis on recht itu merupakan perbuatan yang tidak mentaati larangan atau keharusan yang ditentukan oleh penguasa negara. Sedangkan crimineel on recht itu merupakan perbuatan yang bertentangan dengan hukum.

Bertitik tolak dari berbagai definisi pelanggaran tersebut di atas maka dapat disimpulkan bahwa unsur-unsur pelanggaran adalah sebagai berikut:

a. Adanya perbuatan yang bertentangan dengan perundang-undangan;

b. Menimbulkan akibat hukum 
Berdasarkan berbagai pengertian di atas maka dapat mengambil kesimpulan bahwa pelanggaran adalah suatu perbuatan atau tindakan yang bertentangan dengan ketentuan peraturan perundang-undangan.

Peraturan Daerah Kota Tasikmalaya Nomor 7 Tahun 2015 tentang Pengendalian dan Pengawasan Minuman Beralkohol telah menggariskan pelanggaran terhadap minuman beralkohol yakni sebagaimana dijelaskan pada Pasal 15 ayat (1) Perda ini bahwa setiap orang yang memproduksi, mengimpor dan mengedarkan minuman beralkohol di daerah tanpa izin dari Pejabat yang berwenang berdasarkan ketentuan Peraturan Perundangundangan, termasuk meracik atau mencampur minuman beralkohol untuk kepentingan sendiri dan/ atau orang lain dipidana dengan pidana kurungan paling lama 6 (enam) bulan atau denda paling banyak Rp. 50.000.000,- (lima puluh juta rupiah).

Begitu pula, termasuk pelanggaran Perda ini sebagaimana dijelaskan Pasal 15 ayat (2) yaitu: a. setiap orang yang menyimpan minuman beralkohol untuk kepentingan sendiri dan/ atau orang lain dengan maksud untuk tidak dijual; b. menyajikan minuman berlakohol untuk kepentingan sendiri dan/ atau orang lain dengan tidak untuk dijual; c. mengkonsumsi minuman beralkohol.

\section{Hasil Penelitian dan Pembahasan}

a. Implementasi ketentuan ancaman pidana dalam Peraturan Daerah Kota Tasikmalaya Nomor 7 Tahun 2015 tentang Pengendalian dan Pengawasan Minuman Beralkohol di Kota Tasikmalaya

Alasan diterbitkan Peraturan Daerah Kota Tasikmalaya Nomor 7 Tahun 2015 tentang Pengendalian dan Pengawasan Minuman Beralkohol di Kota Tasikmalaya adalah berdasarkan Peraturan Presiden Nomor 74 Tahun 2013 tentang Pengendalian dan Pengawasan Minuman beralkohol. Terlebih, Kota Tasikmalaya dikenal sebagai kota dengan masyarakat yang religius dan minuman beralkohol mempunyai dampak yang kurang baik yang berbahaya bagi kesehatan baik secara fisik maupun psikis dan dapat berpotensi mengganggu ketentraman dan ketertiban masyarakat.

Realitanya, meskipun telah diatur dan ditentukan ancaman pidananya, masih saja terlihat adanya peredaran minuman beralkohol untuk kepentingan diri sendiri dan masih sering pula dijumpai adanya orang-orang yang 
mengkonsumsi minuman beralkohol serta mabuk-mabukan di tempat-tempat terbuka ataupun di ruang tertutup. Hal tersebut terjadi yakni manakala adanya pentas-pentas seni, hiburan dan kegiatan lainnya.

Berdasarkan hasil wawancara dengan bagian Sabhara Polres Tasikmalaya Kota, diperoleh informasi bahwa di dalam operasi Penyakit Masyarakat (selanjutnya disebut Pekat) yang dilakukan, terdapat orang yang mengkonsumsi alkohol yang mabuk dan diamankan dan dibawa ke Polres dan setelah itu diadakan pendataan dan pembinaan serta diminta untuk membuat pernyataan bahwa tidak akan mengulangi lagi perbuataannya. Sedangkan bagi anak-anak yang mengkonsumsi minuman beralkohol selain didata dan dibuat surat pernyataan, mereka juga dipanggil orang tuanya agar meningkatkan pengawasan terhadap anak-anaknya dan diperingati agar bila mengulangi perbuataannya akan diproses secara hukum.

Pasal 9 Peraturan Daerah Kota Tasikmalaya Nomor 7 Tahun 2015 tentang Pengendalian dan Pengawasan Minuman Beralkohol, melarang mengenai:

1) Menyimpan minuman beralkohol menyimpan minuman beralkohol untuk kepentingan sendiri dan/ atau orang lain dengan maksud untuk tidak dijual;

2) Menyajikan minuman berlakohol untuk kepentingan sendiri dan / atau orang lain dengan tidak untuk dijual;

3) Mengkonsumsi minuman beralkohol.

Berdasarkan hasil penelitian bahwa ketentuan pidana yang ditentukan dalam pasal 15 ayat (2) Huruf $C$ tentang ancaman pidana kurungan paling lama 6 (enam) bulan dan denda paling banyak Rp. 50.000.000,- (lima puluh juta rupiah), belum diterapkan sesuai dengan ketentuan tersebut karena pelaksanaannya masih terbatas pembinaan dan pengendalian yang dilakukan Polres bila terjaring dalam operasi Pekat dengan didata dan disuruh membuat pernyataan tidak akan mengulangi perbuatannya lagi. Oleh karena itu, dapat disimpulkan bahwa ketentuan Pasal 15 ayat (2) huruf $C$ Perda ini belum dapat diimplementasikan secara baik, sesuai dengan tujuan dibentuknya Peraturan Daerah Kota Tasikmalaya Nomor 7 Tahun 2015 
tersebut. Salah sebabnya adalah karena usia Perda ini masih prematur dan belum tersosialisasinya secara maksimal Perda ini di Kota Tasikmalaya.

b. Kendala-kendala dalam implementasi ketentuan ancaman pidana dalam Peraturan Daerah Kota Tasikmalaya Nomor 7 Tahun 2015 tentang Pengendalian dan Pengawasan Minuman Beralkohol di Kota Tasikmalaya

Beberapa kendala dalam ancaman pidana Peraturan Daerah Kota Tasikmalaya Nomor 7 Tahun 2015 tentang Pengendalian dan Pengawasan Minuman Beralkohol di Kota Tasikmalaya adalah sebagai berikut:

1) Kurangnya sosialisasi secara intensif dari Pemerintah Daerah Kota Tasikmalaya tentang Perda ini.

Sosialisasi yang dilaksanakan terbatas pada penyampaian informasi melalui Pemerintah Kelurahan untuk disosialisasikan kepada warganya. Satuan Polisi Pamong Praja (selanjutnya disingkat Satpol PP) yang merupakan instansi yang berwenang dalam penegakan Perda ini, masih kurang berkoordinasi dengan Kepolisian dalam melaksanakan Perda ini, termasuk dalam penegakan hukumnya. Masyarakat Kota Tasikmalaya dan sekitarnya masih banyak yang belum mengetahui Perda ini, sehingga perlu adanya peningkatan sosialisasi melalui berbagai media dan kegiatan-kegiatan terutama kepada pelajar, mahasiswa dan para pengungnjung tempat hiburan.

Wewenang pengawasan konsumsi minuman beralkohol dalam lingkup Polres Tasikmalaya Kota, adalah tugas Sabhara dengan kualifikasi sebagai Penyakit Masyarakat (Pekat) sesuai dengan Undangundang Nomor 2 Tahun 2002 tentang Kepolisian Negara Republik Indonesia serta dalam hal pelaksanaan Perda, tugas Sabhara adalah membantu dan mendukung serta bersama-sama dengan Satpol PP untuk melaksanakan pengendalian dan pengawasan minuman beralkohol di Kota Tasikmalaya. Bahkan keberadaan Perda ini belum diketahui oleh sebagian besar anggota Kepolisian Polres Tasikmalaya Kota, termasuk di jajaran Sabhara itu sendiri, sehingga penegakan dan implementasi ketentuan pidana Pasal 15 ayat (2) huruf C ini tidak terlaksana sesuai harapan. 


\section{2) Penegakan Hukum}

Kurangnya waktu penertiban yang diagendakan oleh aparat penegak hukum sehingga pelaku pelanggaran masih mempunyai peluang mengedarkan minuman beralkohol secara ilegal. Masalah waktu penertiban minuman beralkohol sebagaimana telah disebutkan di atas adalah masalah yang menyangkut tugas dan wewenang berbagai instansi dan lembaga baik yang dibawah pemerintah maupun swasta, oleh karena itu untuk penertiban alkohol di Indonesia terdapat peraturan perundang-undangan yang berhubungan dengan para petugas.

Kehadiran hukum dan manajemen dengan pendekatan sistem yaitu pola pengaturan minuman beralkohol dari seri perdagangan, penyerahan daya dan dana yang meliputi mekanisme bekerjanya instansi dan kementerian sampai kantor- kantor wilayahnya terkoordinasi, penegakan hukum, prosedur acara pidana dan sebagainya yang digerakkan dalam suatu mekanisme yang mapan dan lancar yang dapat mempengaruhi penertiban tersebut.

3) Hukumnya Sendiri

Penerapan sanksi bagi pelanggar yang terlalu ringan, sehingga masih ada pelaku yang mengulangi pelanggarannya. Pelanggaran terhadap peredaran minuman beralkohol di Kota Tasikmalaya termasuk dalam kategori ringan karena hanya diancam dengan pidana kurungan paling lama 6 (enam) bulan kurungan atau denda paling banyak Rp. 50 000.000,- (lima puluh juta rupiah). Selain sanksi sebagaimana dimaksud di atas, kepada pengedar atau penjual hanya dibebani biaya pemusnahan apabila minuman beralkohol yang disita, diputuskan untuk dimusnahkan memerlukan biaya pemusnahan. Jenis tindak pidananya pun hanya dikategorikan adalah pelanggaran, bukan merupakan suatu kejahatan.

Selain kendala di atas, berikut sejumlah kendala Satpol PP dalam melakukan pengawasan terkait dalam penegakan hukum dalam penjualan minuman beralkohol : 
1) Faktor Dari Dalam

a) Keterbatasannya jumlah petugas Satpol PP yang pada umumnya masih kurang memuaskan. Besarnya masalah yang dihadapi di lapangan tidak sesuai dengan jumlah aparat dalam melakukan tugasnya.

b) Kendala serius lain yang dihadapi oleh Satpol PP dalam melakukan penegakan Perda ini dan menciptakan ketentraman serta ketertiban di tengah masyarakat adalah keterbatasan sarana dan prasarana yang tersedia.

c) Dalam banyak hal tidak sedikit aparat Satpol PP merasakan bahwa terbatasnya alokasi anggaran yang diberikan oleh Pemerintah Daerah ternyata memberikan pengaruh cukup signifikan terhadap kinerja mereka.

2) Faktor Dari Luar

a) Salah satu faktor penyebab kurang efektifnya pelaksanaan Perda di tingkat masyarakat adalah belum maksimal dan meratanya langkah sosialisasi Perda yang dilakukan di tingkat masyarakat luas, sehingga masih cukup banyak warga masyarakat yang belum memperoleh pemahaman optimal dalam proses internalisasi nilainilai atau aturan-aturan yang terkandung dalam Peraturan Daerah. Bagi Satpol PP, upaya untuk menegakkan pelaksanaan Perda tentu menjadi lebih sulit.

b) Persoalan penegakan Perda sesungguhnya juga dapat dikaji melalui sisi masyarakat. Artinya masalah penegakan Perda, penciptaan ketentraman dan ketertiban tidak terlepas dari kondisi sosial kultural ekonomi serta politik yang berkembang di lingkungan masyarakat. Rendahnya tingkat pendidikan, lemahnya akses warga masyarakat terhadap sumber informasi yang signifikan, keterbatasan kondisi ekonomi, lemahnya pemahaman dan penafsiran terhadap peraturan yang ada, munculnya kepentingan politis tertentu, unsur kebiasaaan atau nilai-nilai kultural yang berkembang di masyarakat merupakan sebagian dari sekian banyak faktor yang dapat 
memberikan kontribusi terhadap efektivitas penegakan Perda yang dilakukan.

c) Faktor masyarakat yang sulit diajak untuk bekerja sama dengan Satpol PP Kota Tasikmalaya dalam memberikan kesaksian di dalam proses penegakan hukum terhadap tempat-tempat penjualan minuman beralkohol yang dianggap telah mengganggu ketertiban umum. Masyarakat yang selalu diam dan enggan untuk melapor, padahal masyarakat mengetahui keberadaan penjual minuman beralkohol tersebut.

d) Adanya kebocoran terlebih dahulu saat melakukan razia atau operasi. Razia yang dilakukan secara berkala atau dengan waktu tertentu ini terlebih dulu bocor atau sudah diketahui penjual. Kebocoran tersebut bisa berasal dari dalam maupun luar pihak Satpol PP. Hal ini sangat menyulitkan pihak Satpol PP dalam melakukan razia.

e) Dalam hal implementasi Perda, kendala yang kerapkali muncul adalah adanya keterbatasan Perda itu sendiri, di mana dalam Perda dinilai belum mengatur persoalan sanksi atau ancaman yang memadai, sehingga terkesan peraturan yang mendukung pelaksanaan Perda kurang jelas dan tegas. Di samping itu kurangnya dukungan dari semua pihak (baik eksekutif maupun legislatif) dalam menerapkan sanksi Perda. Sanksi yang kurang tegas dan sangat ringan yang diberikan bagi para penjual minuman beralkohol tesebut. Jadi para penjual minuman beralkohol tidak merasa jera dikarenakan sanksi yang tercantum sangat ringan dan cenderung untuk mengulangi perbuatan atau tetap menjual minuman beralkohol. Dan dilhat dari fakta yang ada bahwa sanksi yang diberikan oleh para penjual minuman beralkohol hanya berupa penyitaan minuman beralkohol dan pada sanksi lainnya ialah denda yang sangat jauh lebih ringan dari denda yang tercantum dalam peraturan daerah tersebut.

f) Masih adanya kekeliruan penilaian masyarakat terhadap Satpol PP yang terkadang dituding hanya sebagai tukang obrak abrik yang tidak peka pada masalah kemanusiaan dan penderitaan orang kecil, 
sehingga menyulitkan upaya Satpol PP untuk mengembangkan dukungan dari berbagai kelompok serta organisasi sosial-politik dan warga masyarakat pada umumnya dalam upaya pemeliharaan ketertiban dan ketentraman.

c. Upaya Pemerintah Daerah dan Satpol PP dalam implementasi ketentuan ancaman pidana Peraturan Daerah Kota Tasikmalaya Nomor 7 Tahun 2015 tentang Pengendalian dan Pengawasan Minuman Beralkohol di Kota Tasikmalaya

Kendala-kendala yang ada di atas ini memang sangat menghambat lancarnya penegakan Peraturan Daerah Kota Tasikmalaya terkait dengan pengawasan minuman beralkohol. Satpol PP memiliki upaya-upaya dalam mengatasi penjualan minuman beralkohol tersebut khususnya pada pengawasannya.

Pengawasan yang dilakukan yang pertama ialah pengawasan dari dalam dan pengawasan dari luar. Pengawasan dari dalam berupa pelaksanaan Razia yang dilakukan oleh Satpol PP Kota Tasikmalaya secara berkala. Pengawasan dari luar yang didasarkan pada laporan dari masyarakat kepada Satpol PP tentang tempat-tempat penjualan yang dianggap melanggar dan merasahkan maupun mengganggu ketertiban umum di masyarakat. Kemudian dalam pengawasan yang dilakukan yakni melakukan razia yang langsung terhadap tempat-tempat penjualan minuman beralkohol yang dilaporkan masyarakat.

Pengawasan yang kedua berupa pembinaan terhadap tempat-tempat penjualan minuman beralkohol illegal. Pembinaan, himbauan juga sosialisasi tentang Peraturan Daerah Kota Tasikmalaya kepada penjual minuman beralkohol.

Pengawasan yang ketiga penertiban terhadap tempat-tempat penjualan minuman beralkohol secara illegal. Upaya penertiban ini berupa penyitaan minuman beralkohol yang dilakukan oleh Satpol PP Kota Tasikmalaya. Penertiban tempat-tempat penjual minuman beralkohol yang tidak sesuai dengan ketentuan Peraturan Daerah dapat dikenai sanksi sesuai ketentuan pidana yang berlaku.

Pengawasan secara tidak langsung dilaksanakan lewat pembuatan laporan baik dalam bentuk lisan maupun tulisan. Salah satunya adalah 
pengawasan represif yakni pengawasan yang dilaksanakan pada akhir selesainya kegiatan, kegiatan pengawasannya berupa tindakan perbaikan terhadap setiap tindakan yang dianggap dapat menimbulkan masalah kerusakan dari suatu perbuatan.

\section{Kesimpulan dan Saran}

a. Kesimpulan

1) Implementasi ketentuan ancaman pidana dalam Peraturan Daerah Kota Tasikmalaya Nomor 7 Tahun 2015 tentang Pengendalian dan Pengawasan Minuman Beralkohol di Kota Tasikmalaya, belum sesuai dengan tujuannya atau belum diimplementasikan sebagaimana mestinya karena Perda ini masih prematur, baru 2 tahun dan masih dalam tahap sosialisasi

2) Kendala dalam implementasi ketentuan ancaman pidana dalam Peraturan Daerah Kota Tasikmalaya Nomor 7 Tahun 2015 tentang Pengendalian dan Pengawasan Minuman Beralkohol di Kota Tasikmalaya, yaitu; a. kurang efektifnya dan belum maksimal serta merata langkah sosialisasi Perda yang dilakukan; b. masyarakat yang sulit diajak untuk bekerja sama dengan Satpol PP Kota Tasikmalaya dalam memberikan kesaksian di dalam proses penegakan hukum terhadap tempat-tempat penjualan minuman beralkohol yang dianggap telah mengganggu ketertiban umum; c. adanya kebocoran terlebih dahulu saat melakukan razia atau operasi; d. Perda dinilai belum mengatur persoalan sanksi atau ancaman yang memadai, sehingga terkesan peraturan yang mendukung pelaksanaan Perda kurang jelas dan tegas; e. masih adanya kekeliruan penilaian masyarakat terhadap Satpol PP yang terkadang dituding hanya sebagai tukang obrak abrik yang tidak peka pada masalah kemanusiaan dan penderitaan orang kecil.

b. Saran

1) Sebaiknya sosialisasi Peraturan Daerah Kota Tasikmalaya Nomor 7 Tahun 2015 tentang Pengendalian dan Pengawasan Minuman Beralkohol di Kota Tasikmalaya terus menerus dilaksanakan dimulai 
dengan melakukan tindakan terhadap pelanggaran Pasal 9 Perda ini dan menerapkan sanksi yang diatur dalam Pasal 15 Perda ini.

2) Perlu ditingkatkan upaya Pemerintah Daerah Kota Tasikmalaya terhadap fungsi Satpol PP dengan terus mengadakan operasi-operasi dalam penegakan Peraturan Daerah Kota Tasikmalaya Nomor 7 Tahun 2015 tentang Pengendalian dan Pengawasan Minuman Beralkohol di Kota Tasikmalaya, serta bersama aparat Kepolisian untuk selanjutnya diberikan tindakan tegas kepada pelanggarnya.

\section{Daftar Pustaka}

Aminudin, 2010, Bahaya Alkohol Bagi Kesehatan, Jakarta, Quadra.

Anangsyah, 2000, Pengaruh Minuman Beralkohol Bagi Tubuh Manusia. Surabaya, Erlangga.

Hamzah, Andi, 1986, Kamus Hukum, Jakarta, Ghalia Indonesia.

Hasibuan, Malayu S.P, 2010, Manajemen Sumber Daya Manusia : Edisi Revisi, Jakarta, Bumi Aksara.

Mulyadi, Dedi, 2015, Studi Kebijakan Publik dan Pelayanan Publik, Bandung, Alfabeta.

Nawawi, Zaidan, 2013, Manajemen Pemerintahan, Jakarta, PT Rajagrafindo

Poernomo, Bambang, 2002, Dalam Asas-Asas Hukum Pidana, Ghalia Indonesia, Jakarta.

Prodjodikoro, Wirjono, 2003, Asas-asas Hukum Pidana, Refika Aditama, Bandung.

Pusat Bahasa Departemen Pendidikan Nasional, 2008, Kamus Besar Bahasa Indonesia, Jakarta, Pusat Bahasa.

Subarsono, 2005, Analisi Kebijakan Publik, Yogyakarta, Pustaka Pelajar.

Subhi, Asep dan Ahmad Taufik, 2004, Penggolongan Alkohol dan penyalahgunaannya. Jakarta, PT. Gramedia.

Sukarno K, 1992, Dasar-Dasar Managemen, Jakarta , Miswar. 1992.

\section{Peraturan Perundangan}

Undang-undang Nomor 2 Tahun 2002 tentang Kepolisian Negara Republik Indonesia 
Peraturan Presiden Nomor 74 Tahun 2013 tentang Pengendalian dan Pengawasan Minuman beralkohol.

Peraturan Menteri Perdagangan Republik Indonesia Nomor 20/MDAG/PER/4/2014 tentang Pengendalian dan Pengawasan terhadap Pengadaan Peredaran dan Penjualan Minuman Beralkohol,

Peraturan Daerah Kota Tasikmalaya Nomor 7 Tahun 2015 tentang Pengendalian dan Pengawasan Minuman Beralkohol di Kota Tasikmalaya 